\title{
Production of Biohydrogen from gasification of waste fuels: pilot plant results and deployment prospects
}

\author{
Massimiliano Materazzi ${ }^{\mathrm{a}, \mathrm{b},}{ }^{,}$, Richard Taylor $^{\mathrm{b}}$, Mike Cairns-Terry ${ }^{\mathrm{c}}$ \\ ${ }^{a}$ Department of Chemical Engineering, University College London; Torrington Place, London \\ WC1E 7JE, UK \\ ${ }^{b}$ Advanced Plasma Power Ltd, South Marston Business Park, Swindon SN3 4DE, UK \\ c Progressive Energy Ltd, Swan House, Bonds Mill, Stonehouse, GL10 3RF, UK
}

\begin{abstract}
Hydrogen is seen as a key element of the future energy mix because it does not generate greenhouse gas emissions at the point of use. Understanding the technologies that can generate low carbon hydrogen is essential in planning the development of future gas networks and energy generation via fuel cells. One promising approach is hydrogen production by gasification of waste, referred to as biohydrogen. This paper summarises work undertaken to design a commercial Waste-to-Hydrogen $\left(\mathrm{WtH}_{2}\right)$ plant, which includes an assessment of future markets for hydrogen, the identification of an appropriate scale for the plants, and development of specifications for process design and output streams. An experimental programme was undertaken to demonstrate bioH $_{2}$ production from refuse derived fuel (RDF) at pilot scale and provided experimental data to underpin commercial designs. On this basis, a reference design for small commercial plants was developed for bioH $\mathrm{H}_{2}$ production for heating and transport utilisation. A preliminary carbon assessment shows that carbon savings for
\end{abstract}


biohydrogen in a commercial scale are more than four times greater than alternative technologies.

Keywords: Biohydrogen, Waste Gasification; Waste-to-Hydrogen; Biofuels

\section{Introduction}

In recent years hydrogen has received increasing attention as a potential fuel that could be produced from non-fossil fuel sources (Hart et al., 2015; Barisano et al., 2017; Ogden, 2018), both because it can be generated with low greenhouse-gas (GHG) emissions, and because it generates no emissions at the point of use. Hydrogen is being promoted as an ideal energy vector for heating and transport; assuming that storage and distribution will no longer be an issue in the near future, the outstanding question is how to produce hydrogen with the minimum carbon impact (Balcombe et al., 2018). There are currently two prominent pathways for the production of low carbon hydrogen: one is through reformation of natural gas (by Steam methane reforming (SMR) or Auto-Thermal Reforming (ATR)), combined with carbon capture and storage (CCS). The other one is water electrolysis utilising electricity from renewable sources (e.g. wind and solar).

Steam and autothermal methane reforming involves reacting natural gas with steam or limited amount of oxygen, at high temperatures over a catalyst to produce syngas (a mixture of hydrogen and carbon monoxide). This is then further processed to maximise $\mathrm{H}_{2}$ generation (via water gas shift reaction) and separate $\mathrm{H}_{2}$ product from a $\mathrm{CO}_{2}$-rich stream (Iulianelli et al., 2016). Production capacities of hydrogen from a typical steam methane reforming plant range between 150 and $440 \mathrm{MW}$ with an energy efficiency of typically 70\% (Ogden, 2018). Traditionally, a major part of the hydrogen consumption in oil and gas refineries is covered by 
hydrogen produced as a by-product from other refinery processes or from SMR, which also represent a major source of carbon released into the atmosphere from petroleum industries (Al-Salem, 2015). If SMR is to become a major low-carbon source of hydrogen, carbon capture and storage is essential. It is estimated that between $71 \%$ and $92 \%$ of the $\mathrm{CO}_{2}$ in steam methane reforming can be captured (Rubin et al., 2012); however higher capture rates will be needed if the process is to be used in the long term. Furthermore, CCS barriers are no exclusively technical, with CCS cost being the most significant hurdle in the short to medium term (Budinis et al., 2018). Among the new developments to produce low carbon hydrogen from methane is the sorption-enhanced SMR, which combines steam-reforming of methane and $\mathrm{CO}_{2}$ absorption together in a single step. This configuration has two major advantages: on the one hand, the produced $\mathrm{H}_{2}$ can have a purity of $98 \%$ with only a small amount (ppm level) of $\mathrm{CO}$ and $\mathrm{CO}_{2}$ thus minimizing the requirement on purification (Di Giuliano et al., 2018). On the other hand, the continuous removal of the produced $\mathrm{CO}_{2}$ from the system by a solid absorbent pushes the reaction to completion, enhancing hydrogen yields significantly. SMR and sorption-enhanced $\mathrm{H}_{2}$ production have been covered by a few excellent reviews (Barelli et al., 2008; Shokrollahi et al., 2016; Wu et al., 2016; Di Giuliano et al., 2018). The key challenge of the latter is the multicycle durability of $\mathrm{CO}_{2}$ absorbent, which must be improved.

Water electrolysis also offers a small-scale solution that can be cost effective for some applications such as filling stations for hydrogen vehicles (Zeng and Zhang, 2010). However, currently the cost of hydrogen produced by electrolysis is far more expensive than SMR hydrogen ( $£ 6.20 / \mathrm{kg}$ versus $£ 1.90 / \mathrm{kg}$ for transport-grade) and it does not offer significant greenhouse gas (GHG) benefits unless renewable electricity is used. Power-to-gas (PtG) technologies rely on this principle. This development is particularly attractive due to the 
availability of renewable power generation in excess of immediate electricity demand and an expectation that this availability will increase with the share of intermittent renewable power generation (Götz et al., 2016).

Several techniques have been proposed by many researchers for the thermal conversion of solid organic materials to hydrogen rich syngas, via gasification or pyrolysis (Siedlecki and de Jong, 2011; Bocci et al., 2014; Miandad et al., 2016; Al-Salem et al., 2017; Barisano et al., 2017). The hydrogen can then be separated and upgraded to a product referred to as biohydrogen $\left(\mathrm{bioH}_{2}\right)$. Biohydrogen offers the prospect of low carbon hydrogen production from low-grade - in large fraction renewable - fuels, at parity with the cost of natural gas, and with the potential of negative carbon emissions if the separated $\mathrm{CO}_{2}$ is sequestered (Zech et al., 2015). A number of studies have been reported in the literature for biohydrogen production from first-generation biomasses, especially from starchy and sugar-rich biomasses due to easy fermentability attribute of these feedstocks by anaerobic organisms which increases $\mathrm{H}_{2}$ yield compared to other organic substrates (Chong et al., 2009; Argun et al.). The biggest obstacle when using these sources as feedstock is the utilization of land and clean water to produce energy crops instead of food production. Furthermore, there is a debate over the environmental impact of biofuels agriculture related to over-usage of water and fertilizers (Molino et al., 2018).

Waste and second-generation biomass materials, although readily available and abundant, have limited uses in terms of chemical feedstocks, due to the need for pre-treatment and presence of many contaminants which add complexity and costs (Materazzi and Lettieri, 2017a). Thermochemical treatment of waste for hydrogen or chemical production, therefore, presents a number of unique issues demanding specific design choices and technical 
solutions. Generally speaking, the conversion schemes use heat and various combinations of steam, oxygen and $\mathrm{CO}_{2}$, to convert the feedstock to various amounts of char, hydrocarbon gases, hydrogen, and carbon oxides, with ash being a by-product of most waste feedstocks (Basu, 2010). Ash residues are usually classified as a hazardous waste on account of their high alkalinity and other pollutant species (e.g. heavy metals and soluble chloride and sulphate salts); as such, they require specific treatment before disposal (Chang et al., 2009). Therefore,

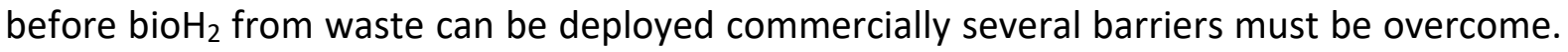
Firstly, the technical feasibility of hydrogen production from waste derived feedstock must be demonstrated to show that the concept is credible. Secondly, the process must be optimised for commercial deployment, with designs produced, environmental impact understood and costs modelled. Finally, the chosen designs must be deployed at larger scale, with hydrogen supplied to end users. Extensive work is needed to push forward commercial deployment of hydrogen production from waste by systematically working to address each barrier.

This paper details the provisions taken to address these challenges and the reasoning behind them. In doing so it draws out some of the common challenges faced by the industry and the way in which the proposed approach, in particular how the syngas is produced, confers certain advantages when it comes to use of a syngas in a catalytic conversion process. Within this context, Section 2 summarises work undertaken to define a functional specification for a commercial Waste-to-Hydrogen $\left(\mathrm{WtH}_{2}\right)$ plant, which includes an assessment of future markets for hydrogen, an appropriate scale for the plants, and development of specifications for output streams. Section 3 describes the experimental programme, which demonstrated bioH $_{2}$ production from waste at pilot scale and provided experimental data to underpin commercial designs. Section 4 summarises the reference design developed for commercial 
bioH $_{2}$ production and discusses the drivers behind design choices. Future process improvements are also identified, along with an early stage assessment of carbon emissions.

\section{Waste-to-Hydrogen plant: challenges and prospects}

While biohydrogen production has traditionally focused on homogeneous biomass, more difficult feedstocks, such as municipal and other solid waste streams, could find application. The overall process presented in this work has focused on waste feedstocks, primarily municipal solid waste (MSW), as this represents the most technically challenging feedstock with the highest treatment costs, and will be the focus of early plants in the future. Feedstocks such as wood would require minimal process adjustments from conventional Biomass to Methanol (BtM) or Biomass to Liquids (BtL) plants, and have largely been discussed elsewhere (Bridgwater, 2003). This section provides an overview of the main transformation steps for production of $\mathrm{bioH}_{2}$ from wastes. The specification for the baseline feedstock, scale of operation, and product use are discussed for the final plant design.

\subsection{Hydrogen use and distribution}

Hydrogen has been viewed as a potential vector to decarbonise transport for the last two decades. Currently electrification is seen as one of the prime pathway for decarbonisation of the passenger vehicle sector and is likely to see larger growth in the short term than adoption of hydrogen. Hydrogen fuels cell cars complement the advantages of electric vehicles by offering extended ranges and faster refuelling, and benefit from development of electric drivetrains, which are common to both (Granovskii et al., 2006). While electrification looks set for a large role in decarbonising cars, there are fewer low carbon solutions for heavy goods vehicles (HGVs) and buses (Hua et al., 2014). Electrification of HGVs is not feasible with 
current battery technology and the charging time for electric buses is a substantial constraint on utilisation. Conversion to biomethane or bioSNG is also one solution (Zhang, 2010). Hydrogen, however, offers zero tailpipe emissions, particularly advantageous for urban environments and buses, which typically operate as back-to-base enabling gradual roll out of hydrogen refuelling infrastructure (Verhelst et al., 2014).

Biohydrogen's potential as a gas for direct heating use is also gaining a considerable attention. Blending hydrogen and natural gas is already undertaken across Europe. In parts of Germany a blend of up to $10 \%$ by volume hydrogen in natural gas is permitted. In Holland, injection of hydrogen up to $20 \%$ by volume was trialled at Ameland (Kippers et al., 2011). Currently the UK gas grid does not accept more than $0.1 \%$ hydrogen by volume (Hodges et al., 2015). However, a site-specific exemption has been granted by the Health and Safety Executive (HSE) to blend hydrogen at $20 \%$ into the gas network at Keele University, and it is anticipated that blending of hydrogen from a variety of sources into the gas distribution could be feasible as early as 2020 (Hodges et al., 2015). Injecting hydrogen into the network to create a blend for use by consumers provides an opportunity for the early roll out of biohydrogen production, since there is significant demand for low carbon replacements for natural gas that are compatible with existing appliances. Furthermore, shifting completely to hydrogen offers a longer-term opportunity for bioH $_{2}$ because it offers far greater carbon savings than SMR hydrogen. However, whilst the national transmission systems are capable of carrying much larger volumes of gas than the distribution networks, there are a number of risks and constraints relating to both the materials of construction and the nature of the gas consumers connected to it, which mean that there are barriers to accommodating hydrogen except in a blend, and at relatively low blending levels (Northern Gas Networks, 2016). These risk levels 
are associated with introducing hydrogen blends into existing natural gas pipeline systems and do not apply to new pipelines dedicated specifically to hydrogen transportation, which are designed and managed differently from the existing natural gas pipeline installations (Witkowski et al., 2018). Worldwide, there are already more than $4,500 \mathrm{~km}$ of hydrogen pipelines in total, the vast majority of which are operated by hydrogen producers. The longest pipelines are operated in the USA, followed by Belgium and Germany (HyARC, 2017).

\subsection{Scale definition and feedstock preparation}

Compared to biomass, MSW materials introduce a greater concentration and diversity of contaminants, due the large number and variability of sourcing points. This presents a major challenge, compounded by the fact that more sophisticated applications (including catalytic processes for bioH $_{2}$ production) have low tolerances. Generally, the design point for the waste composition for a thermochemical facility is derived from a number of datasets for representative residual municipal, commercial and trade waste collected nationally as well as locally. The data presented in the Supplementary Information document gives a design point specification of waste sourced in Western-England. Waste cannot be thermochemically treated in the form it is when collected. The untreated municipal or commercial waste is first mechanically processed in a materials recycling facility (MRF). This is done to homogenise the material and remove part of the moisture, recyclables (for example, metals and dense plastics) and reject materials (for example, oversize and inerts). The material is then shredded using tearing motion to achieve a rough shred of waste residues, with a homogenous, predetermined particle size between 1-50 mm, depending on the gasification reactor requirements. The final feedstock is in the form of floc RDF (Refuse Derived Fuel), which is then further dried on-site using waste heat from the process. Typically, a 150,000 tonnes 
MSW feed produces an output of ca. 90,000 to 120,000 tonnes of RDF with a moisture content of $10-17 \%, 10-20 \%$ ash content and 15-25 MJ/kg calorific value (CV). MRF plants processing commercial waste (mainly package waste) are usually technically more simple than those processing MSW, with RDF recovery efficiencies of above 80\% (Wilén et al., 2004).

A good potential reference $\mathrm{WtH}_{2}$ plant size could treat around 100,000 tonnes per annum of RDF, this being supplied from a reasonably sized town, accounting for residual domestic, commercial and industrial waste arisings. This is also similar in scale to small conventional energy from waste facilities (Defra, 2014). Bus fleets have been identified as the earliest likely adopters of hydrogen for transport. A typical bus will consume around 5 tonnes per annum of hydrogen. A large depot will operate around 100 buses, i.e. 500 tonnes per annum or 20GWh. This equates to around $5 \%$ of the $\mathrm{WtH}_{2}$ plant scale identified. This suggests that transport applications in the medium term are likely to be serviced by slip streams from larger plants designed to service grid or industrial customer applications.

\subsection{Syngas generation}

The key element for a consistent quantity of $\mathrm{bioH}_{2}$ is the production of a high quality syngas very rich in hydrogen, and suitable for catalytic processing. Ideally, this syngas is free of poisoning contaminants (sulphur and chlorine), tars and nitrogen, the latter difficult and costly to remove from a gas stream product. In order to get the right syngas, both autothermal and allothermal processes can be used. The chemistry and form of the feedstock, as well as scale, means that unlike coal, RDF cannot be processed using established high intensity technologies, like for example entrained flow gasification (Materazzi et al., 2018). Due to their flexibility and robustness, fluidised beds are instead more suitable for small applications and for treating gross and heterogeneous feedstock (Materazzi and Lettieri, 2017b; Arena and Di 
Gregorio, 2016). For Waste-to-Gas applications, autothermal fluidised bed processes need to be carried out with pure oxygen as gasification agent. In order to deliver sufficient pure oxygen without getting to high temperature, oxygen/steam mixtures are typically used in practical applications. This will result in a product gas with medium calorific values, very low nitrogen, medium to high hydrogen, and low hydrocarbon contents (mostly methane in few percent) in the product gas. The $\mathrm{H}_{2}: \mathrm{CO}$ ratio is important for further hydrogen separation, as low values are likely to cause low bioH $\mathrm{H}_{2}$ yield and high $\mathrm{CO}_{2}$ generation during water gas shift. In case of oxygen-steam gasification, $\mathrm{H}_{2}: \mathrm{CO}$ will be in the order of 1.0 to 1.5 depending on waste : steam ratio or moisture content. Moisture in autothermal reactors in normally limited to below $15 \%$ wt. When high quantities of moisture are present in the initial RDF, the oxidant supply rate must be enhanced to generate sufficient heat to sustain the gasification reaction, resulting in lower syngas heating value (Materazzi et al., 2016a). As temperature within the bed has to be limited to below ash softening point, upstream oxygen enrichment can also be used, although issues arise for the potential hazards associated with oxygen-rich mixtures at high temperatures (Leclerc and Larachi, 2015).

Allothermal gasification processes will typically use steam, or in future $\mathrm{CO}_{2}$, as gasification agents in an externally heated reactor, fast internally circulated fluidised beds (FICFB) or dual fluidised beds (DFB) (Wilk et al., 2011; Leclerc and Larachi, 2015). In this latter configuration, air is used to burn char and/or secondary fuels in a separate chamber to provide heat to an inert bed material (e.g. sand) which is then transferred to a second oxygen-starved unit running in parallel on steam (or $\mathrm{CO}_{2}$ ). Since the process is split in two separate chambers, the produced syngas is not diluted with products of combustion, and $\mathrm{CO}_{2}$ and $\mathrm{N}_{2}$ content within the syngas is significantly low. The focus of industrial work on bioSNG production, for 
example, has largely focused on utilising this type of indirect gasification technologies (Rehling et al., 2011). In principle, these offer a significant thermochemical efficiency advantage for bioSNG production, providing a syngas with as much as $15 \%$ methane. However, this advantage often reflects higher propensity to tars production, as methane is simply the gaseous end of a spectrum of complex and condensable hydrocarbons produced, including volatile organic carbon (VOC), sulphur-containing organic species and condensable oils, which need to be removed (with some inevitable loss of chemical energy from the syngas) (Materazzi et al., 2014). Promising results for a beneficial product gas for bioH production are obtained with steam as gasification agent, this leads to medium calorific values and high hydrogen content in the syngas ( $\mathrm{H}_{2}$ : $\mathrm{CO}$ close to 2.0$) . \mathrm{CO}_{2}$ as gasification agent compared with steam as gasification agent will lead to lower hydrogen and higher carbon monoxide contents and consequently to an essential lower ratio of $\mathrm{H}_{2}$ : $\mathrm{CO}$ (Tancredi et al., 1996).

Another class of allothermal gasification technologies include plasma, often used in combination with other reactors (Fabry et al., 2013). The use of plasma has increasingly been applied with waste treatment for its ability to completely decompose the input material into a tar-free synthetic gas and an inert, environmentally stable, vitreous material known as slag. The principal advantages that plasma offers to thermal conversion processes, besides the already mentioned tar/ash related issues absence, are a smaller installation size for a given waste throughput, and the use of electricity as energy source, characteristics which permit the technology to treat a wide range of heterogeneous and low calorific value materials. This include various hazardous wastes, such as polychlorinated biphenyls (PCBs), medical waste, and low-level radioactive (Gomez et al., 2009; Wang et al., 2009; Byun et al., 2010; Lombardi 
et al., 2015; Sanlisoy and Carpinlioglu, 2017). Vitrified ash products show excellent mechanical and anti-leaching properties, and are suitable as a construction material (Wang et al., 2009). Stand alone or two-stage plasma processes are particularly suitable for processing waste feedstock due to the high quantity of ash, organic and inorganic contaminants, and typical fluctuating quality of the feedstock, notwithstanding that the presence of an air separation unit (ASU) and plasma electrode make the process particularly energy intensive. On the other hand, the issues associated with complex organics and organo-sulphur compounds suggest that indirect gasification has significant drawbacks as a technology for producing syngas to be used in bioH $\mathrm{H}_{2}$ production. However, the advantage of not needing an air separation unit makes these processes attractive for less problematic fuels, i.e. pure biomass.

\subsection{Syngas clean up}

The fuel gas exits the gasification stage at temperature usually higher than $800{ }^{\circ} \mathrm{C}$ and comprises mostly $\mathrm{H}_{2}, \mathrm{CO}, \mathrm{H}_{2} \mathrm{O}$ and $\mathrm{CO}_{2}$ and a number of minor contaminants. After heat recovery, the syngas has to go through a gas cleaning system to remove tars, particulates, vapour phase metals, acid gases (mostly, $\mathrm{Cl}^{-}$and $\mathrm{S}^{-}$based), and a myriad of trace species released from RDF which could hinder the effective syngas utilization downstream. The cleaning from these problematic species down to values that are acceptable for different downstream catalysts are of crucial importance for successful implementation of waste gasification technology, and in particular bioH $\mathrm{H}_{2}$ applications. These systems are asked to deal with a much wider and heterogeneous range of contaminants compared to other biomass applications, and at the same time respond to more stringent specifications dictated by catalysts for $\mathrm{bioH}_{2}$ production. The success of new gasification technologies for the treatment of waste feedstocks in the future will be assessed also on this basis. 
Copper catalysts for biohydrogen production require a level of the contaminant in the gas phase to be below $0.1 \mathrm{ppm}$ to be considered acceptable for commercial use (Ladebeck and Wagner, 2003). In the case of mercury vapour this is generally required to be below $10 \mathrm{ppb}$ to be acceptable (Dunleavy, 2006). Sulphur compounds are widespread in waste derived syngas and the higher molecular weight compounds (i.e. thiophenes) are reasonably refractory, requiring plasma reforming or high temperature hydrotreatment to be removed. Secondary poisons are the metal hydrides (arsine/phosphine) and acid gas components $(\mathrm{HF} / \mathrm{HCl})$. Tertiary poisons are the aromatics and olefins which give rise to polymeric and carbon deposits on the catalyst surface (Seemann et al., 2006). For economic reasons at small scale, the organic sulphur, unsaturated hydrocarbons (e.g. ethylene, acetylene, etc.) and light aromatics arising from lower intensity gasification cannot be removed using physical solvent scrubbing such as Rectisol, and must be dealt with thermal or hydrothermal technologies. When plasma or hydrodesulfurization (HDS) are used, the result is that the remaining contaminants can be removed by a conventional acid and alkali scrubbing. Typical cleaning system for small scale (<100 MW) waste based plants includes tar reforming systems, dry filters (incorporating a ceramic filter unit with chemical sorbents dosing), and alkaline wet scrubbers (Zwart, 2009). The clean syngas is dewatered before being further polished in a series of guard beds for removal of remaining contaminants deleterious to the catalytic process, including dehalogenation, and trace sulphur removal through hydrogenation and desulphurization in $\mathrm{ZnO}$ beds (Asadullah, 2014). An extensive review of gas cleaning methods for syngas polishing is provided by several authors (Woolcock and Brown, 2013; Asadullah, 2014; Abdoulmoumine et al., 2015). 


\subsection{Water Gas Shift reactors}

Hydrogen produced from gasification is not sufficient to sustain a $\mathrm{WtH}_{2}$ plant on its own. Additional $\mathrm{H}_{2}$ is produced by conversion of the $\mathrm{CO}$ in syngas through the water-gas shift (WGS) reaction:

$$
\mathrm{CO}+\mathrm{H}_{2} \mathrm{O} \leftrightarrow \mathrm{H}_{2}+\mathrm{CO}_{2}
$$

This is an exothermic equilibrium reaction with hydrogen production favoured by low temperature, often obtained with two sequential reactors with intercooling stage. The first step is a standard shift catalyst (high temperature shift, or HTS catalysts) which operates at temperatures in excess of $300^{\circ} \mathrm{C}$, limiting $\mathrm{CO}$ conversion. Ferrochrome (Fe- $\mathrm{Cr}$ ) oxide based formulations are the most commonly used high-temperature $\left(320-450{ }^{\circ} \mathrm{C}\right) \mathrm{HTS}$ catalyst (Ratnasamy and Wagner, 2009). In order to achieve high levels of CO conversion, it is necessary to operate a second step at lower temperatures $\left(190-220{ }^{\circ} \mathrm{C}\right)$, using low temperature shift (LTS) catalysts. The most common LTS catalysts are varieties of copper/zinc oxides supported on alumina substrates $\left(\mathrm{Cu} / \mathrm{ZnO} / \mathrm{Al}_{2} \mathrm{O}_{3}\right)($ Gokhale et al., 2008). Both HTS and LTS catalysts are sensitive to sulphur content, with the latter start deactivating at concentration as low as $1 \mathrm{ppm}$. Cobalt/molybdenum (CoMo)-based shift catalysts are instead widely used for syngas streams that contain very high levels of sulphur. In particular, these so-called "sour-shift" catalysts are preferred by plants that use low-temperature bulk desulfurization systems, where the shift catalyst must operate upstream of the gas clean-up system in the presence of up to percent levels of sulphur (Ladebeck and Wagner, 2003). 
Over 100 years of industrial experience on water gas shift for coal to-liquid or gas to-liquids processes, have taken to a large number of publications, and extensive understanding of syngas requirements and reaction mechanisms (Ladebeck and Wagner, 2003; Ratnasamy and Wagner, 2009; Smith et al., 2010). The aim in the $\mathrm{bioH}_{2}$ case is, therefore, to push the WGS reaction to a practical limit, while providing a clean and good quality syngas to ensure high catalyst longevity.

\section{$2.6 \mathrm{CO}_{2}$ removal and upgrading}

The product from WGS is normally a mixture of $\mathrm{H}_{2}$ and $\mathrm{CO}_{2}$, with some other minor components $\left(\mathrm{N}_{2}, \mathrm{CH}_{4}, \mathrm{CO}\right)$ depending on the upstream processes. There are many commercially deployed techniques for separating $\mathrm{CO}_{2}$ from process streams with the optimal solution depending on factors, such as the required specification of the product stream, required $\mathrm{CO}_{2}$ purity, and the temperature and pressure conditions of the inlet and outlet streams. There are two relevant specifications for hydrogen produced by a $\mathrm{WtH}_{2}$ plant presented in this work, namely: bioH $_{2}$ for use in fuel cells: $99.95 \%$ purity, with additional restrictions on certain contaminants (Shabani and Andrews, 2015); $\mathbf{b i o H}_{\mathbf{2}}$ for use in the gas network, in industry, or blended into the natural gas network ("grid-quality"): $<2 \%$ inerts, CO content below 100ppm, some methane can be accommodated (up to 10\% vol) (De Santoli et al., 2017; Kouchachvili and Entchev, 2018).

Commercial plants anticipated in the context of this investigation would produce both but, owing to the limited market for transport-grade hydrogen, less than $10 \%$ of the output would be at transport quality at this stage. Pressure swing adsorption (PSA) is commonly employed to achieve the $99.95 \%$ purity required for use in fuel cells (Asgari et al., 2014). However, several studies have shown that PSA results in significant slip of $\mathrm{H}_{2}$ into the tail gas, reducing 
both product yield and purity of the $\mathrm{CO}_{2}$ stream (Olajire, 2010). Luberti et al. (Luberti et al., 2014) have shown that hydrogen recovery can reach a maximum of $93 \%$ with a Polybed $\mathrm{H}_{2}$ PSA system having twelve columns. The tail gas from PSA can be recirculated back into the main process train when upgrading a small slip stream of high purity hydrogen, but this cannot be done for the whole process stream because the $\mathrm{CO}_{2}$ must ultimately be removed from the system. For this reason and because the $\mathrm{CO}_{2}$ is not of sufficient quality for sequestration, PSAs might be inappropriate for a small scale $\mathrm{WtH}_{2}$ plant. Several other separation technologies could be considered, including membrane separation, physical solvents and amine systems (Granite and O'Brien, 2005; Adhikari and Fernando, 2006; Barelli et al., 2008; Shokrollahi et al., 2016). A good potential solution in this application could be a Benfield-type potassium carbonate system as it offers high $\mathrm{CO}_{2}$ recovery, high $\mathrm{CO}_{2}$ selectivity and good heat integration, with low electrical loads and pressure drop for product stream (Borhani et al., 2015). As a result, the slip of product into the $\mathrm{CO}_{2}$ stream is very low, giving good $\mathrm{H}_{2}$ yields and a captured $\mathrm{CO}_{2}$ stream at a purity suitable for sequestration.

Following $\mathrm{CO}_{2}$ removal, there will be residual $\mathrm{CO}$ in the bioH $\mathrm{H}_{2}$ stream. At this point, a slipstream can be taken for high-purity hydrogen production in a PSA (the tail gas is reintroduced to the process). The bulk of the gas can instead proceed to a CO polishing methanation stage, with a high-nickel catalyst, where residual $\mathrm{CO}$ is converted to methane (Takenaka et al., 2004). The high-activity catalyst ensures that $\mathrm{CO}$ levels are reduced to below $100 \mathrm{ppm}$, as requested by grid quality gas. Methane levels in the hydrogen stream can reach $10 \%$; for grid blending and industrial use, this methane content is operationally beneficial (Kouchachvili and Entchev, 2018). 


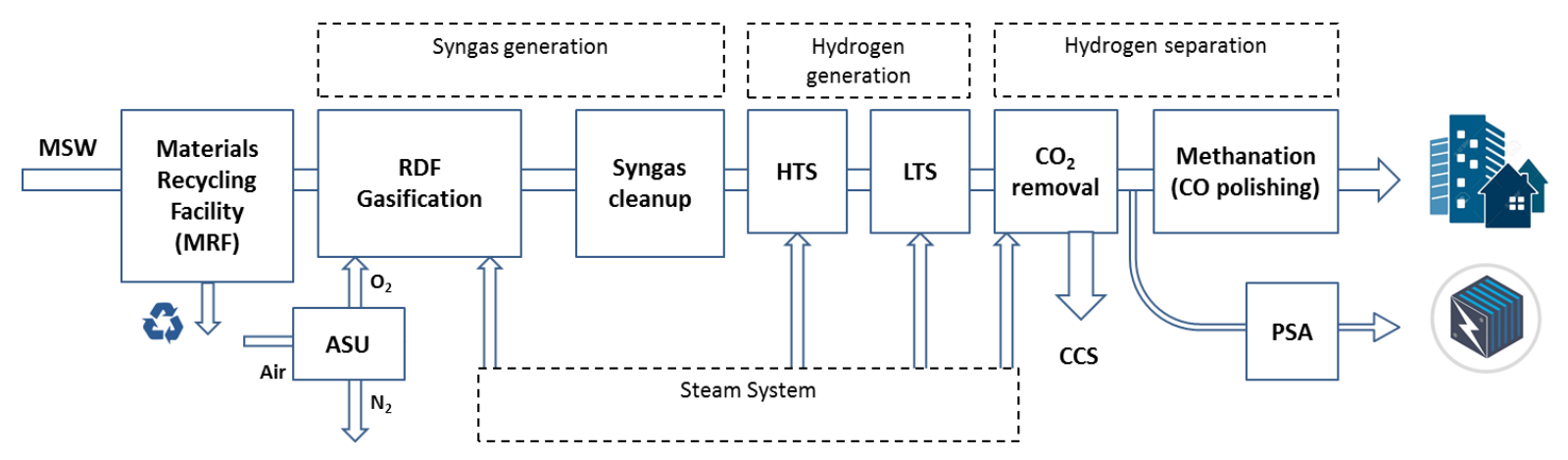

Figure 1 Process flow diagram for a standard commercial $\mathrm{WtH}_{2}$ plant

\section{Pilot scale testing}

This section reports the results of experimental work and of demonstration of $\mathrm{bioH}_{2}$ production at pilot scale. The main specific objectives of the work were to characterise potential catalysts for the process, understanding performance and optimal operating conditions for conversion of waste-derived syngas, and to show that residual CO levels in the product can be reduced to near zero. The latter is particularly important to eliminate the possibility of injecting $\mathrm{CO}$ into the gas network on account of its known toxic potential. Furthermore, production of biohydrogen at scale was demonstrated, including the processing required to utilise waste feedstock with sensitive catalysts. This information would provide from the foregoing an analytical basis for the definition of a full-scale $\mathrm{WtH}_{2}$ process.

In pursuit of these objectives, practical investigations and demonstrations were undertaken utilising existing assets from the earlier small-scale bioSNG plant developed in Swindon (UK). 
These comprise a 500kW gasification facility, which replicates all of the system elements that would constitute the syngas production train in a commercial-scale plant, as shown in the process flow diagram (Figure 2). The syngas is then used in a second facility on site to prove the production of biohydrogen from real waste derived syngas. A full description of the two parts of the plant is provided in this section.

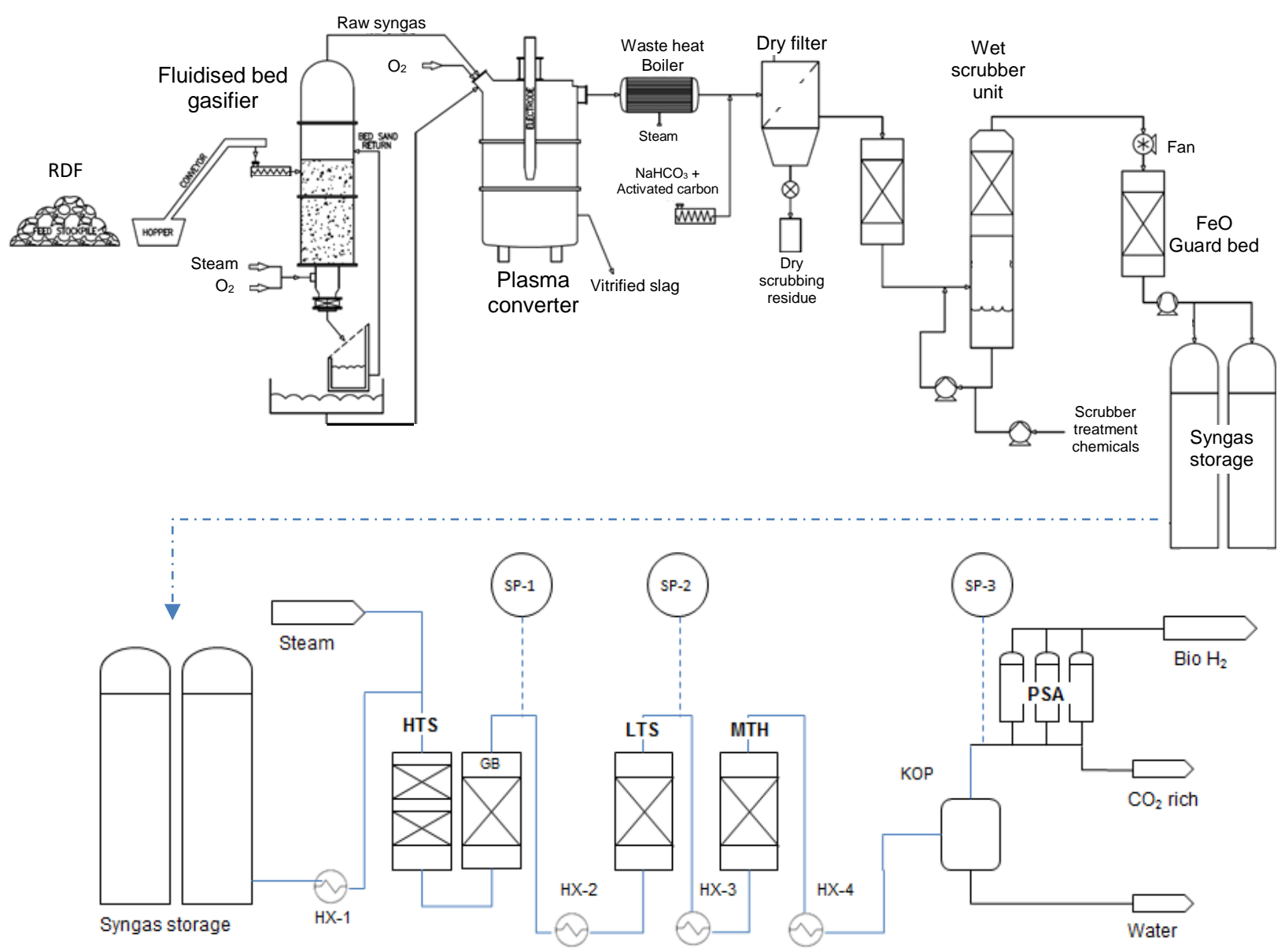

Figure 2: $500 \mathrm{~kW}$ pilot gasification plant for clean syngas production (top), $50 \mathrm{~kW} \mathrm{bioH_{2 }}$ production from stored syngas (bottom) 


\subsection{Syngas generation plant}

The gasification process is a combination of two distinct thermal process steps. The first is a bubbling fluidised bed gasifier operated at $700-800{ }^{\circ} \mathrm{C}$, in which steam and oxygen are used to partially oxidise the RDF. In the second step, the crude syngas produced by the bubbling bed gasifier is refined in a separate plasma converter (Materazzi et al., 2016b). The plasma converter completely degrades complex hydrocarbons and tars reducing them to a clean syngas stream along with simple inorganic contaminants such as hydrogen sulphide and hydrogen chloride, which are readily removed with conventional gas scrubbing techniques. The choice of a two-stage process is not imperative, but it ensures the production of a consistent quantity of syngas from a chemically and physically heterogeneous feedstock, of a quality suitable for chemical transformation as opposed to energy production. With this respect, the reforming action of electric plasma not only ensures stable operation and higher conversion efficiency (due to the conversion of tars and fly char into more $\mathrm{H}_{2}$ and $\mathrm{CO}$ ), but also breaks down covalently bound organic sulphur (e.g. thiophenes, thioles, and their derivatives) and other problematic contaminants which would be hardly removed by conventional scrubbers. Thiophene in particular, although rarely measured in small scale plants, has been found to be particularly detrimental in catalytic systems, even at below ppm levels, due to the high sensitivity of synthesis catalysts to sulphur in all its forms (Rabou and Bos, 2012). Furthermore, the large fraction of ash contained in RDF is recovered as vitrified slag from the converter. The vitreous alumino-calcium-silicate matrix of the slag has also been shown to immobilise some hazardous heavy metals and decrease their leachability. The results of the leaching test are reported in other publications and show compliance with limits for inert landfill materials (Materazzi et al., 2015a, Materazzi et al., 2015b). This is a 
particularly important aspect in waste treatment facilities because it ensures that only minimum residues (mostly for air pollution control and gas cleaning media) are sent to treatment and disposal (Materazzi et al., 2015a). Downstream of the plasma arc converter, the syngas is cooled to below $200{ }^{\circ} \mathrm{C}$ in a heat exchanger prior to treatment to remove any residual particulates and elementary acid gas contaminants (mostly, $\mathrm{HCl}, \mathrm{COS}$, and $\mathrm{H}_{2} \mathrm{~S}$ ). This includes a dry filter (incorporating a ceramic filter unit with sodium bicarbonate and activated carbon dosing), and an oxidative alkaline wet scrubber. This provides bulk removal of nitrogenous compounds, chloride, fluoride, and simple sulphur gases present prior to demisting to reduce entrained water. An iron oxide pellet guard bed is used for any residual sulphur scavenging. Slightly negative pressure $(5-10 \mathrm{mbarg})$ is maintained throughout the process using an induced draft (ID) fan located after the wet scrubber. The outlet of the ID fan defines the system boundary between the original $500 \mathrm{~kW}_{\text {th }}$ gasification pilot facility and the hydrogen production plant. In order to separate the operation of the two plants, the syngas from the gasification process is compressed and stored. The syngas is generated at approximately 0.05 barg pressure and is compressed to 50 barg through a four-stage reciprocating compressor, featuring interstage cooling with condensate removal. The compressed syngas is then supplied to the syngas store, which comprises four identical gas storage vessels. These vessels are capable of holding approximately 1.2 tonnes of compressed syngas, whose composition for the tests reported in this work is reported in Table 1. Details for the operation of the $500 \mathrm{~kW}_{\text {th }}$ gasification pilot facility for syngas generation are reported elsewhere (Materazzi et al., 2018).

Table 1 RDF and Syngas specification used for baseline tests

\begin{tabular}{|c|c|}
\hline RDF (as received) & $\begin{array}{c}\text { Characterisation of cleaned syngas } \\
\text { From storage }\end{array}$ \\
\hline
\end{tabular}




\begin{tabular}{|c|c|c|c|c|c|}
\hline \multicolumn{3}{|c|}{ Proximate analysis } & \multicolumn{2}{|c|}{ Composition: } & \\
\hline Fixed carbon & weight $\%$ & 6.4 & $\mathrm{H}_{2}$ & vol.\% & 35.77 \\
\hline Volatile matter & weight $\%$ & 59.6 & $\mathrm{CO}$ & vol.\% & 33.20 \\
\hline Ash & weight $\%$ & 19.1 & $\mathrm{CO}_{2}$ & vol.\% & 23.54 \\
\hline Moisture & weight $\%$ & 14.9 & $\mathrm{CH}_{4}$ & vol.\% & 1.67 \\
\hline \multirow{2}{*}{\multicolumn{3}{|c|}{ Ultimate analysis }} & $\mathrm{H}_{2} \mathrm{O}$ & vol.\% & 0.89 \\
\hline & & & Other & vol.\% & 4.90 \\
\hline $\mathrm{C}$ & weight $\%$ & 41.0 & TOTAL & vol.\% & 100.00 \\
\hline $\mathrm{H}$ & weight $\%$ & 5.7 & \multicolumn{2}{|c|}{ Trace contaminants } & \\
\hline $\mathrm{O}$ & weight $\%$ & 17.5 & $\mathrm{H}_{2} \mathrm{~S}+\mathrm{COS}$ & ppmv & $<50$ \\
\hline $\mathrm{N}$ & weight $\%$ & 1.2 & Organic sulphur & ppmv & $<30$ \\
\hline $\mathrm{S}$ & weight \% & 0.2 & Tars (+C6) & $\mu \mathrm{g} / \mathrm{m}^{3}$ & $<18$ \\
\hline $\mathrm{Cl}$ & weight $\%$ & 0.4 & Acetylene & ppmv & $<40$ \\
\hline \multicolumn{6}{|l|}{ Energy Analysis } \\
\hline GCV (dry) & $\mathrm{MJ} / \mathrm{kg}$ & 22.1 & $\mathrm{NCV}$ (dry) & $\mathrm{MJ} / \mathrm{kg}$ & 8.75 \\
\hline
\end{tabular}

When the second part of the plant (Figure 2, bottom) is in operation for bioH $\mathrm{H}_{2}$ production, this receives syngas from the high pressure store and a heater electrically heats the syngas before releasing the pressure to the required plant operating pressure (in the range 1 to 10 barg). This initial heating is required to prevent the formation of solid, frozen carbon dioxide in the process pipework due to excess cooling during pressure reduction.

\subsection{Water Gas Shift stages}

The syngas is then electrically heated by a further heater $(\mathrm{HX}-1)$ to $400^{\circ} \mathrm{C}$. A controlled flow of deionised water is added, which is then vaporised to form steam. The steam-laden syngas provides the feed gas to the water gas shift reactor. Because of the small-scale of the plant, heat losses necessitated the use of electric blankets around reactors to ensure components were maintained at sufficient temperature. This will not be necessary on commercial plants where heat losses relative to process thermal loads would be negligible. The HTS comprises a tubular reaction vessel containing a suspended canister containing undiluted catalyst beads, supplied by Johnson Matthey (KATALCO 71-5). The amount of catalyst was selected on the basis of a range of gas hourly space velocity (GHSV) at which the system was close to 
thermodynamic equilibrium. At this point residual COS in the gas (if present) would also be hydrolysed to produce $\mathrm{H}_{2} \mathrm{~S}$. The shifted syngas from the HTS passes through a single guard bed tubular reactor (GB) containing a suspended canister of zinc oxide in which any residual sulphur contaminants (principally hydrogen sulphide) within the gas are removed. Some or all of the cleaned, shifted syngas from the Guard Bed passes through a water-cooled heat exchanger ( $\mathrm{HX}-2)$ so as to cool the gas to a temperature appropriate for that required for downstream second water gas shift (LTS) stage. The LTS reactor is identical in size to the HTS, and filled with Cu-based catalyst (KATALCO 83). During the course of the test programme it became clear that shift reactions alone would not be sufficient to remove $\mathrm{CO}$ to the levels required and so the programme was expanded to investigate methanation as a solution to this problem. The cooled shifted syngas is therefore fed to a single methanation reactor of the same size of the previous WGS reactors. A high activity $22 \% \mathrm{Ni}-\mathrm{Ca}-\mathrm{Al}_{2} \mathrm{O}_{3}$ (Catal Ltd), mixed with inert alumina beads (50:50 wt.\%), was used in MTH to aim at complete CO conversion.

\subsection{Product Gas Conditioning}

From the final methanation reactor $(\mathrm{MTH})$ the methanation product gas is cooled through a water-cooled heat exchange unit ( $\mathrm{HX}-4)$ and thence to a knock-out pot (KOP) where any condensed water droplet are separated and removed from the gas stream. This gas mixture is then passed to a pressure PSA unit where the gases are separated from one another to yield a pure $\mathrm{H}_{2}$ product stream and a carbon dioxide-rich tail gas stream. The plant has been specifically designed to operate over a broad range of conditions, with flows of up to $51 \mathrm{~kW}$ (of thermo-chemical energy) of hydrogen product gas, and at reaction pressures of between 1 and 20 barg. 
The gas composition is continuously monitored using an IR Xentra 4210 analyser in the gasification facility, a Gasmet Fourier Transform Infrared (FTIR) Continuous Emissions

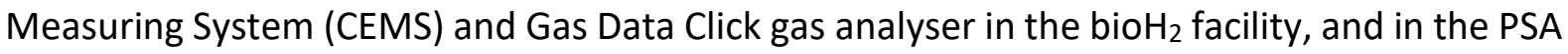
unit a Siemens Ultramat 23 for $\mathrm{CO} / \mathrm{CO}_{2}$ and a Siemens Calormat for $\mathrm{H}_{2}$. Three gas sampling locations SP-1, SP-2, SP-3 were used to measure gas composition using the FTIR, i.e. downstream the HTS, LTS and MTH respectively.

\section{Results and Discussion}

\subsection{Plant start-up and System tuning}

The $50 \mathrm{~kW}$ bioH $\mathrm{H}_{2}$ pilot plant was operated for approximately 4 days, with the first 12 hours used for warm up, catalyst reduction and system tuning. The catalytic beds were externally heated at adequate reduction temperature $\left(180-230{ }^{\circ} \mathrm{C}\right)$ and treated in sequence with a continuous flow of bottled hydrogen $\left(20 \%\right.$ vol. in $\left.\mathrm{N}_{2}\right)$ for several hours until temperature profiles inside the beds were mostly flat. This was the indication that the fresh, oxidised metal catalysts inside the vessels were fully reduced and ready to operate on syngas. Clean syngas from the gas storage vessels was then diverted to the system at increasing flowrate, and between 5 and 7 barg delivery pressure. Controlled flow of water was added to the system immediately prior to the electrical heater. Combined flow of gas through the reactor was sufficient to give a GHSV of between 5000 and $11000 \mathrm{~h}^{-1}$.

Symmetrical trends of $\mathrm{CO}$ and $\mathrm{CO}_{2}$ were observed in the first HTS reactor reflecting the occurrence of water gas shift as the dominating reaction from temperatures above $250^{\circ} \mathrm{C}$ (Figure 3). CO conversion increased from $10 \%$ to above $60 \%$ as the temperature was increased through the system. Simultaneously, the change in the temperature profile with time-on- 
stream in the reactor was stable and in line with expected trends. Temperature profile gradually spread out across the reactor, along with an increase in CO conversion, until reaching equilibrium conditions at $\sim 340^{\circ} \mathrm{C}$ after $\sim 4$ hours of operation.
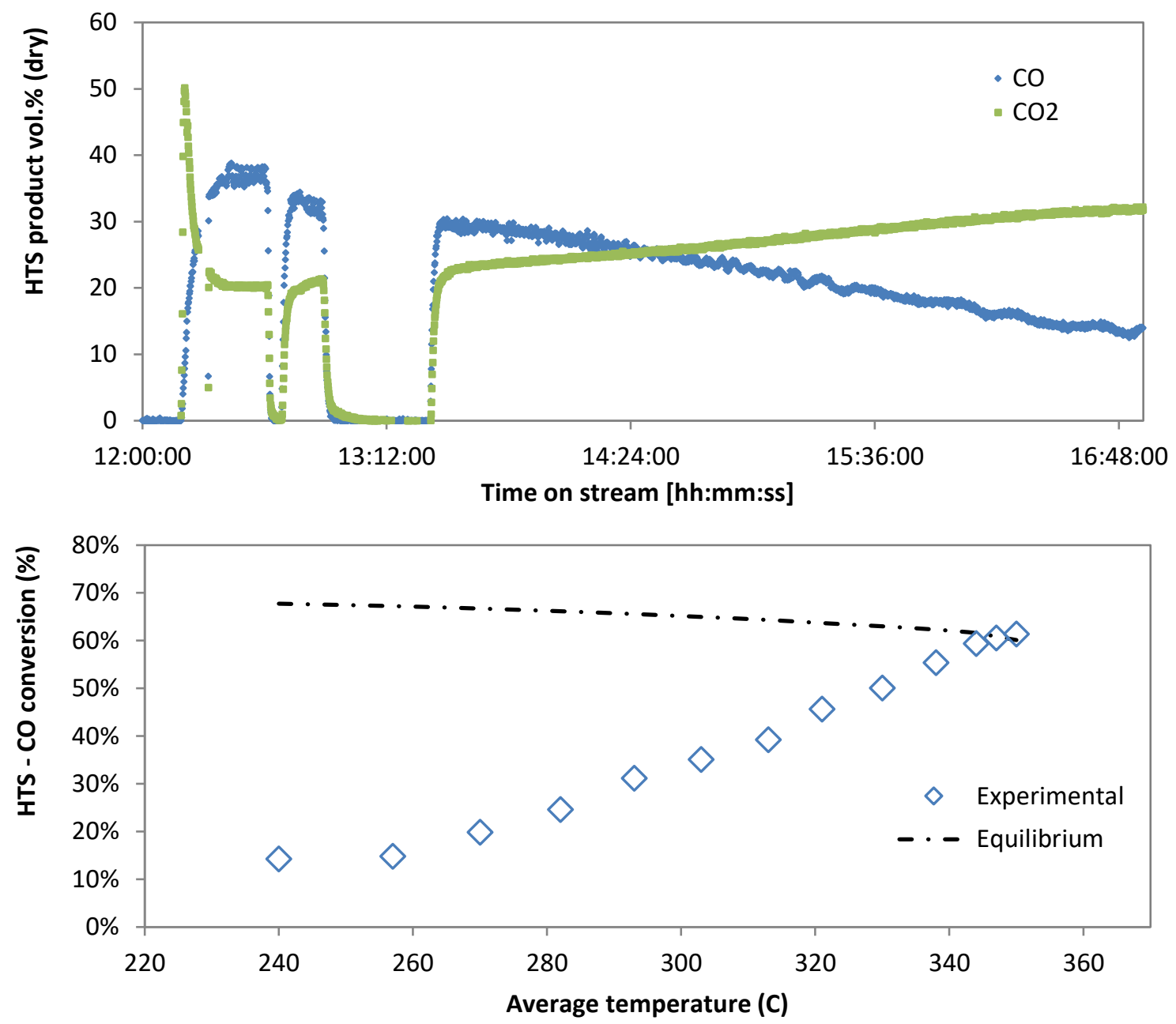

Figure 3: $\mathrm{CO}-\mathrm{CO}_{2}$ measurement (SP-1) and $\mathrm{CO}$ conversion recorded during HTS start up (Steam:CO $=1.4$, syngas inlet composition as in Table 1, GHSV:7800 $\mathrm{h}^{-1}$ )

A broad range of conditions were tried but the lowest product gas $\mathrm{CO}$ content achieved in the HTS was around 8 vol\%, with conversions of $\mathrm{CO}$ of $50-60 \%$ at $340{ }^{\circ} \mathrm{C}$. Such performance was found even with great excesses of water vapour present. Switching gas sampling location to position SP-2 showed that LTS was also working effectively towards reducing CO. The LTS 
reactor is better operated at about $200^{\circ} \mathrm{C}$ inlet temperature and reduce the CO level from typical inlet levels of $9-10 \mathrm{~mol} \%$ (dry) to $1-3 \mathrm{~mol} \%$ (dry). Higher conversion could be potentially achieved for lower inlet CO levels. Different steam:CO ratios were also tested, as shown in Figure 4. As steam is injected before HTS, the curves reflect the enhanced conversion for both HTS and LTS stages. When $\mathrm{H}_{2} \mathrm{O}: \mathrm{CO}$ was increased from 1.4 to 2.2 a decrease in residual CO was observed, indicating that a slight excess amount of water helps in pushing the reaction towards the final products.

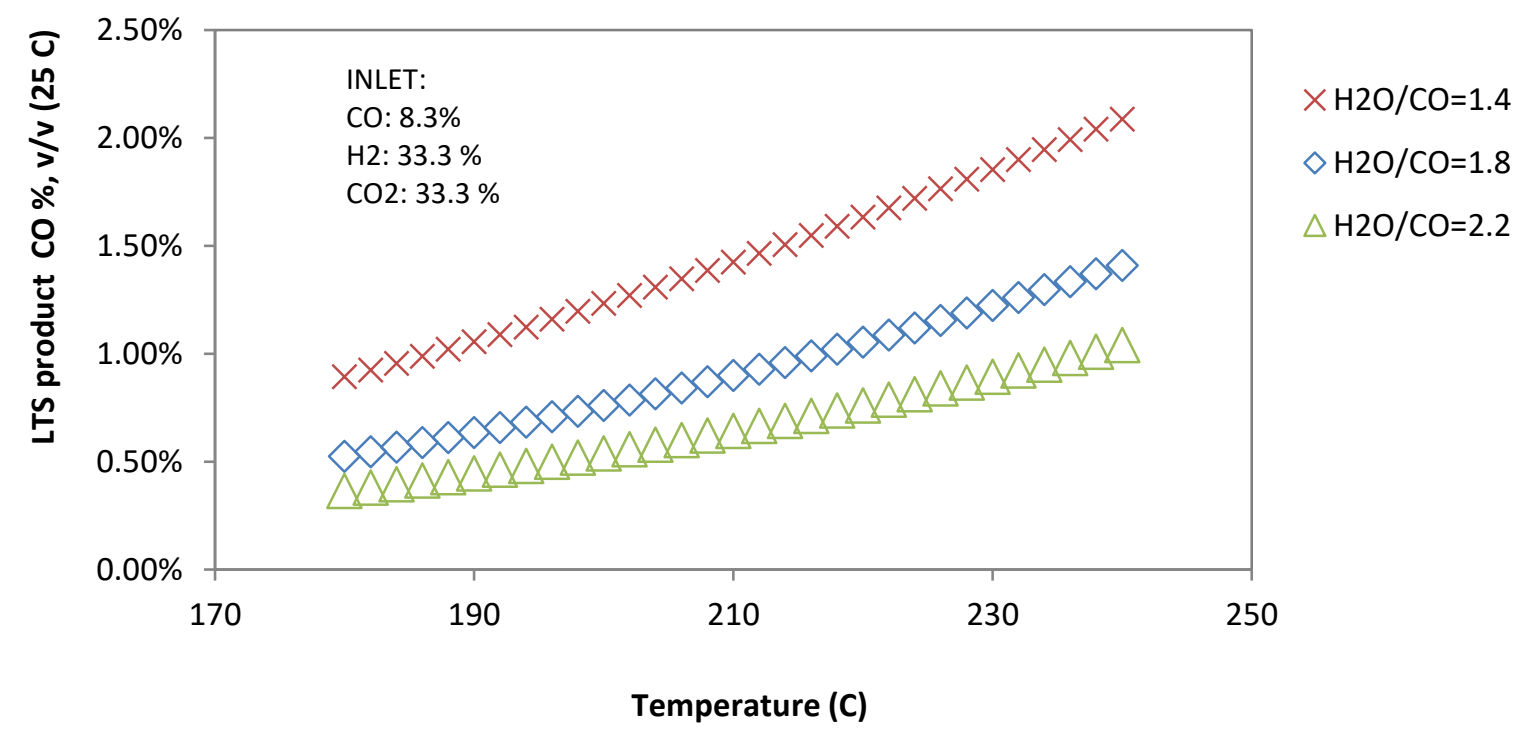

Figure 4 LTS - CO outlet concentration (SP-2) for different $\mathrm{H}_{2} \mathrm{O}$ :CO ratio

Higher $\mathrm{H}_{2} \mathrm{O}: \mathrm{CO}$ ratio were not tried as this could have caused pore saturation (Ratnasamy and Wagner, 2009). Excessive steam feeding the WGS reaction has two beneficial effects: it increases equilibrium conversion and disfavours coke formation. It is concluded, therefore, that for the examined catalysts the most appropriate reaction condition is a $\mathrm{H}_{2} \mathrm{O}: \mathrm{CO}$ molar ratio of approximately 2 .

\subsection{Gas compositions at different locations}


Figure 5 contains a snapshot of the gas compositions generated throughout the process. Total CO conversion was $92.1 \%$ through both HTS and LTS reactors, with the HTS achieving, on occasions, $62 \% . \mathrm{H}_{2}: \mathrm{CO}$ molar ratio increased from $1: 1$ in the syngas from the gas store, to 3.1:1 in the HTS to a final 15.9:1 in LTS product gas. The methanation reactor achieved CO concentrations of below $1 \%$, a value in line with equilibrium predictions and literature data at $230{ }^{\circ} \mathrm{C}$. Close to $100 \%$ CO conversion could be achieved with higher Nickel catalyst $(40-50 \%$ wt.) active at lower temperatures $\left(180-200{ }^{\circ} \mathrm{C}\right)$, or by removing the bulk of $\mathrm{CO}_{2}$ upstream. Most importantly, no catalyst deactivation could be observed during the 4 days of continuous operation. This confirms that the sensitive catalysts are operating as expected on waste derived syngas in the pilot plant and provides confidence that the proposed production configuration is viable. Future research will focus on further observations on the integrated system, possible catalyst deactivation during long term (> $2000 \mathrm{~h}$ ) trials, and $\mathrm{CO}_{2}$ separation by means of chemical processes.

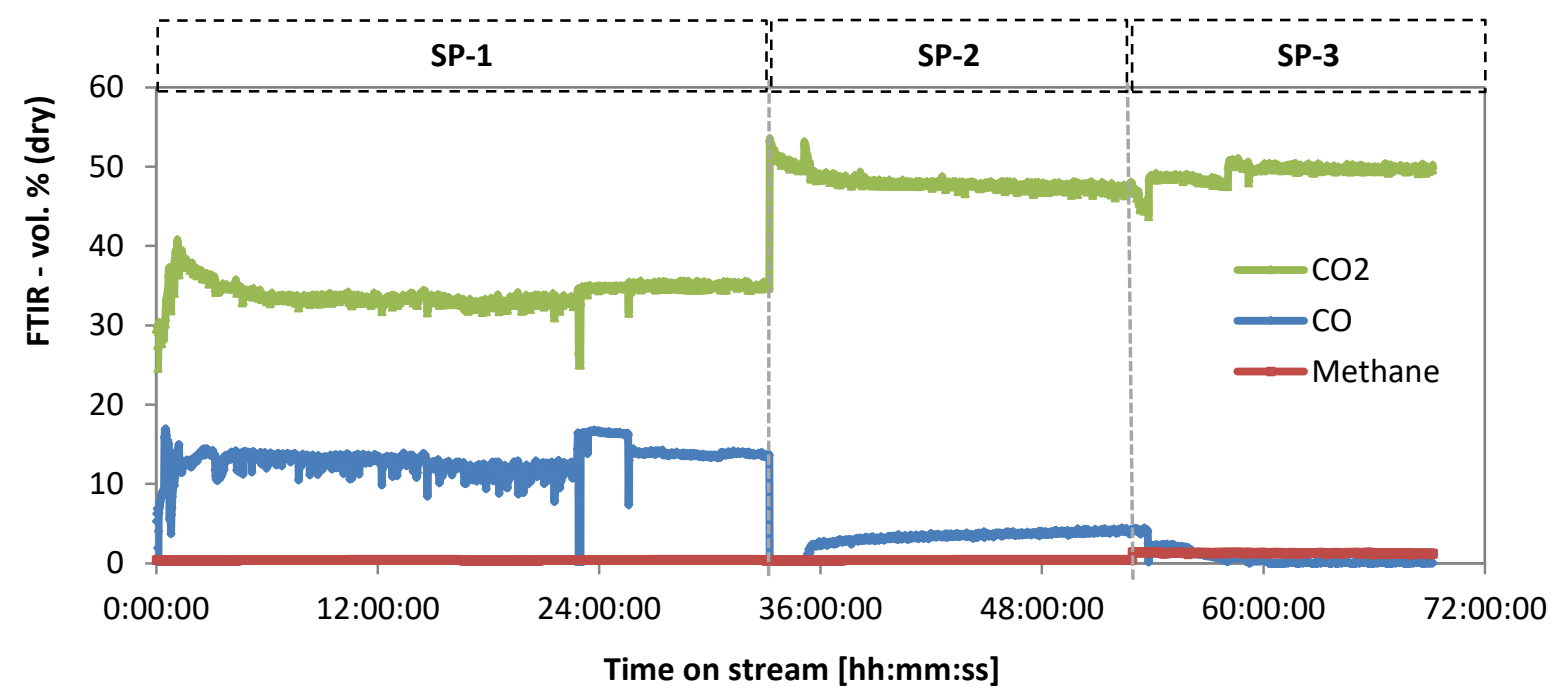

Figure $5 \mathrm{FTIR}$ readings for $\mathrm{CO}, \mathrm{CO}_{2}$ and Methane during entire run at different sampling locations 


\subsection{Full scale Plant considerations}

This section summarises the process design for the proposed $\mathrm{WtH}_{2}$ plant on the basis of pilot plant results, and developed to meet the functional specification described in Section 2. The baseline design is for a commercial-scale $\mathrm{WtH}_{2}$ plant, producing $360 \mathrm{GWh}$ per annum of hydrogen (grid quality) from refuse derived fuel (RDF) or similar biomass-rich feedstock, 23GWh of which would be high-purity hydrogen for use in transport applications. A full mass and energy balance was produced for commercial plant configurations, incorporating process models produced during the experimental work described. The aim of the projection was to establish the environmental benefits of biohydrogen production from waste as represented in Figure 1. Steam and heat generated were assumed to be used internally and not considered, for example, for further electricity production. This allows a more conservative estimation to be provided. Details of the full mass and energy balances of the gasification plant and associated emissions can be found elsewhere (Evangelisti et al., 2015; Tagliaferri et al., 2016; Manson-Whitton, 2017). The energy-basis Sankey diagram and the key parameters for the process model are reported in the Supporting Information document.

The cold gas efficiency (CGE) of the process is projected to be slightly lower than $70 \%$, which is in line with those of other biohydrogen plants based on biomass (Ni et al., 2006; Zech et al., 2015). Main differences are due to the additional electrical input for gas cleaning and ash vitrification owed to operation on waste. The quantity of $\mathrm{CO}_{2}$ captured ( 18 tonnes per hour) is significantly higher than from other Waste-to-Gas facilities, like bioSNG, meaning that the environmental benefit of bioH $_{2}$ production is significantly greater where CCS is available 
(Tagliaferri et al., 2016). This is because in the $\mathrm{WtH}_{2}$ case, close to $100 \%$ of the carbon initially present in $\mathrm{RDF}$ is recovered as $\mathrm{CO}_{2}$ product.

To better understand the environmental benefit of $\mathrm{bioH}_{2}$, an early assessment of the carbon emissions associated with the process described hereby was attempted. Although a full Life Cycle Assessment was not possible due to the lack of full emissions data of a real commercial plant, a high level estimation of $\mathrm{CO}_{2}$ emissions associated to production and avoided burdens could be made. The baseline for this analysis considered a commercial plant producing 360GWh/annum of 'grid-quality' biohydrogen from RDF. This is similar to the facility described in previous section, the only difference being that no transport-grade hydrogen is produced (the impact on greenhouse gas performance of this change is minimal). For comparison, the plant was considered with and without carbon capture and storage.

Any analysis of carbon emissions must be clear about the boundary of the system considered, and the counterfactual for $\mathrm{CO}_{2}$ emissions. In this case, boundaries include emissions associated with production and transport of material inputs and product use. For the $\mathrm{CO}_{2}$ emissions counterfactual, one approach in the renewables industry is to consider emissions derived from biogenic carbon to be zero and fossil-derived carbon emissions to have the global warming potential (GWP) of $\mathrm{CO}_{2}$ (Christensen et al., 2009). This approach ignores the particular issues associated with a waste feedstock. In fact, if not treated in thermochemical facilities, waste must be always disposed of, generally either by incineration or landfill. Therefore, these should be the counterfactuals against which waste-to-fuels processes are evaluated. Incinerators convert the vast majority of fossil and biogenic carbon in the feedstock to $\mathrm{CO}_{2}$. Taking this as a counterfactual, $\mathrm{CO}_{2}$ emissions associated with fossil carbon in the feedstock should be discounted because they would have been emitted in any case. 
When waste is landfilled the biogenic content decomposes and produces methane, a greenhouse gas 23-25 times as damaging as carbon dioxide. Emissions associated with landfill are therefore far greater than those associated with incineration (Cherubini et al., 2009). A conservative approach is to take incineration as the counterfactual and discount all $\mathrm{CO}_{2}$ emissions arising from carbon in the feedstock; that is the basis for this analysis. For clarity, the full assessment also considers emissions associated with transport of municipal waste and RDF, production of dry RDF from municipal waste, production of biohydrogen from RDF (electricity, oxygen, chemicals), and final separation and capture of $\mathrm{CO}_{2}$, as reported in Table 2. The assumption is made that the product is injected into the national gas grid, with exact pressures depending on plant location, potentially but not necessarily requiring some further compression. Therefore, this is excluded from the calculation. Emissions at the point of use are taken to be zero; emissions arising from small quantities of methane combustion in the mix are ignored because of the incineration counterfactual. The carbon intensity of electricity used in the process is an important factor and is rapidly reducing in the UK. For this analysis, operation in $\mathbf{2 0 2 0}$ was assumed and an average taken of the carbon intensities from all four scenarios given in National Grid's 2017 Future Energy Scenarios (FES) (National Grid, 2017). The intensity used was therefore $174 \mathrm{kgCO}_{2} / \mathrm{MWh}$. Emissions from each process step for the capture and non-capture cases, are given in Table 2, per megawatt hour of bioH $\mathrm{H}_{2}$ on a higher heating value basis. Savings against natural gas are given using the EU grid mix value of $243 \mathrm{kgCO}_{2 \mathrm{eq}} / \mathrm{MWh}$ (Edwards et al., 2007). 
Table 2: Consumption and carbon emissions, per $\mathrm{MWh} \mathrm{BioH}_{2}$ produced

\begin{tabular}{|c|c|c|c|c|}
\hline \multirow[t]{2}{*}{ Contribution: } & \multirow[t]{2}{*}{ Assumptions: } & \multicolumn{2}{|c|}{$\begin{array}{c}\text { Emissions } \\
\left(\mathrm{kgCO}_{2 \mathrm{eq}} / \mathrm{MWh}\right)\end{array}$} & \multirow[t]{2}{*}{ References: } \\
\hline & & CCS & No CCS & \\
\hline Feedstock transport & $\begin{array}{l}\text { The waste used in these plants will be collected } \\
\text { locally, typically from sites within a } 10 \mathrm{~km} \text { radius } \\
\text { of RDF processing plant which will in turn be a } \\
\text { short distance from the biohydrogen facility. }\end{array}$ & 0.9 & 0.9 & $\begin{array}{l}\text { (Evangelisti et al. } \\
\text { 2015) }\end{array}$ \\
\hline RDF production & $\begin{array}{l}\text { Ofgem's UK Solid and Gaseous Biomass Carbon } \\
\text { Calculator gives electricity, diesel and sulphuric } \\
\text { acid use figures for a range of RDF production } \\
\text { configurations (Ofgem n.d.). Figures for an } \\
\text { aerobic digestion-type facility have been used }\end{array}$ & 8.1 & 8.1 & (Ofgem n.d.) \\
\hline Biohydrogen plant & \multicolumn{4}{|c|}{ The main emissions associated with the $\mathrm{WtH}_{2}$ plant itself derive from : } \\
\hline $\begin{array}{r}\text { Electricity } \\
\text { ASU } \\
\text { Chemicals }\end{array}$ & $\begin{array}{l}\text { Imported electricity for plasma, compressors, } \\
\text { and other ancillaries (0.148MWhe/MWh with } \\
\mathrm{CCS}, 0.122 \mathrm{MWh} / \mathrm{MWh} \text { otherwise) } \\
\text { Oxygen production (103kg/MWh) } \\
\text { Adsorbants, catalysts, etc. }\end{array}$ & $\begin{array}{c}25.8 \\
12\end{array}$ & $\begin{array}{c}21.2 \\
12\end{array}$ & $\begin{array}{c}\text { (Tagliaferri et al. } \\
\text { 2016; Evangelisti } \\
\text { et al. 2015) } \\
\text { (Tagliaferri et al. } \\
\text { 2016; Evangelisti } \\
\text { et al. 2015) } \\
\text { (Tagliaferri et al. } \\
\text { 2016; Evangelisti } \\
\text { et al. 2015) }\end{array}$ \\
\hline $\mathrm{CO}_{2}$ capture & $\begin{array}{l}\text { The biohydrogen process captures carbon } \\
\text { dioxide at sufficient quality for long-term } \\
\text { sequestration }\end{array}$ & $\begin{array}{l}372 \\
\text { (captured) }\end{array}$ & - & $\begin{array}{l}\text { (Von Der Assen et } \\
\text { al. 2014; } \\
\text { Northern Gas } \\
\text { Networks 2016) }\end{array}$ \\
\hline Total: & & (322) & 46 & \\
\hline $\begin{array}{l}\text { Total saving versus } \\
\text { natural gas }\end{array}$ & $\begin{array}{l}\text { Natural gas EU grid mix value: } \\
243 \mathrm{kgCO}_{2 \mathrm{eq}} / \mathrm{MWh}\end{array}$ & 565 & 198 & $\begin{array}{c}\text { (Edwards et al. } \\
\text { 2007) }\end{array}$ \\
\hline
\end{tabular}

The total figures compare well with those for bioSNG calculated in another study, with a $462 \mathrm{kgCO}_{2 \text { eq }} / \mathrm{MWh}$ saving with carbon capture $(211 \%)$ or $207 \mathrm{kgCO}_{2 \text { eq }} / \mathrm{MWh}(85 \%)$ without (Tagliaferri et al., 2016). In addition, hydrogen from electrolysis results much more carbon intensive. Assuming a commercial electrolyser efficiency to be $50 \mathrm{kWh} / \mathrm{kg} \mathrm{H}$, and the same $\mathrm{CO}_{2}$ emissions associated to use of electricity, approximately $220 \mathrm{~kg}$ of $\mathrm{CO}_{2}$ equivalent are emitted per MWh of hydrogen produced, as also shown in (Bertuccioli et al., 2014). $\mathrm{WtH}_{2}$ 
plant without access to sequestration has significantly lower emissions (by approximately $75 \mathrm{kgCO}_{2 \text { eq }} / \mathrm{MWh}$ ). SMR-derived hydrogen results in a $59 \%$ saving, according to another study (Northern Gas Networks, 2016); using the same emissions factors as in this assessment would give $51 \%$ savings (saving $123 \mathrm{kgCO}_{2 \text { eq }} / \mathrm{MWh}$ ). The analysis clearly shows the advantage of biohydrogen production from waste in this case too. When compared with SMR hydrogen with $\mathrm{CCS}$, a $\mathrm{WtH}_{2}$ plant without access to sequestration has significantly lower emissions (by $75 \mathrm{kgCO}_{2 \text { eq }} / \mathrm{MWh}$ ). Where a $\mathrm{WtH}_{2}$ plant can access $\mathrm{CO}_{2}$ sequestration it achieves substantial negative emissions of $322 \mathrm{kgCO}_{2 \mathrm{eq}} / \mathrm{MWh}$, which is $442 \mathrm{kgCO}{ }_{2 \mathrm{eq}} / \mathrm{MWh}$ lower than SMR with CCS and $540 \mathrm{kgCO}_{2 \text { eq }} / \mathrm{MWh}$ lower than hydrogen from electrolysis. The comparison between carbon emissions of all $\mathrm{H}_{2}$ production pathways is illustrated in Figure 6. It is worthwhile noting that with projected decarbonisation targets in both the UK and Europe, this conclusion could be reversed in the future and grid connected water electrolysers can offer significant carbon benefits per unit of hydrogen.

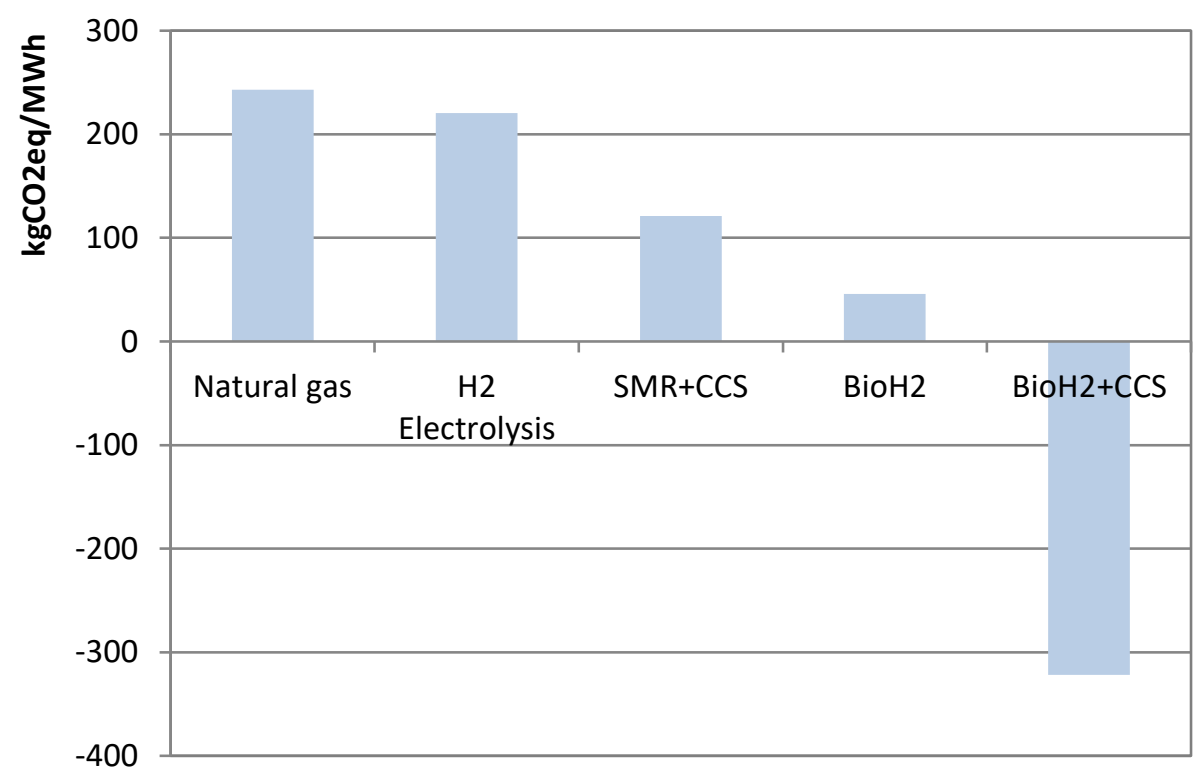

Figure 6 Carbon intensity of different gas production methods 
The economics of the three processes (electrolysis, $\mathrm{SMR}$ and $\mathrm{WtH}_{2}$ ) are quite different, and an accurate economic analysis was beyond the scope of this work. According to a recent report, as the technology matures, a commercial waste bioH $_{2}$ plant should produce a gas with a similar levelised cost to hydrogen produced by SMR with CCS, and significantly lower than the cost of hydrogen produced by electrolysis using off peak electricity (Manson-Whitton, 2017). This is because, as for other thermochemical plants, a $\mathrm{WtH}_{2}$ plant has relatively high capital costs but operating costs are subsidised by the waste gate fees. On the other hand, capital costs for SMR are lower but the cost of the natural gas feedstock makes operating costs high. Similarly, the significant operating costs for electrolysis are driven by the costs of electricity (Ogden, 2018). The key advantage of biohydrogen is the depth of decarbonisation it offers when combined with CCS. This high GHG saving results in very low costs for each tonne of carbon dioxide saved.

The key disadvantage for $\mathrm{WtH}_{2}$ is that its potential is limited by the availability of sustainable feedstock. This could be supplemented by imported biomass but the imported volumes are hard to forecast. If CCS infrastructure is developed then wholesale conversion of parts of the gas network may take place, as also described in (Northern Gas Networks, 2016). If this is the case, then biohydrogen should be able to compete with SMR on cost while offering significantly increased $\mathrm{CO}_{2}$ savings.

\section{Conclusions}

Low carbon hydrogen is seen as a key element of the future energy mix mostly because it generates no greenhouse gas emissions at the point of use. Understanding the technologies 
that can generate low carbon hydrogen is essential in planning the future gas network and energy generation via fuel cells. One promising approach is hydrogen production by gasification of waste, referred to as biohydrogen. This work sought to lay much of the groundwork necessary to understand how $\mathrm{WtH}_{2}$ can be developed, and biohydrogen deployed. Early commercial $\mathrm{WtH}_{2}$ plants would better be designed to service grid or industrial customer applications. In the medium term, transport applications could be serviced by slip streams from larger plants.

An experimental campaign was undertaken on a modified plant originally designed for bioSNG production. The work has confirmed that the combination of steam-oxygen fluidised bed gasification and plasma refining delivers a high quality raw gas with very low levels of contaminants, while dealing at the same time with the increased amount of ashes by producing a vitrified inert product. The downstream gas processing and polishing techniques have been shown to provide syngas of sufficient quality for catalyst operation. During the time of operation examined, there was no evidence of induced degradation, nor other contamination or deactivation. A two-stage water gas shift process and methanation polishing step are able to produce significant yields of biohydrogen and high conversion efficiencies. However, the resulting $\mathrm{CO}$ content is not compliant with gas grid regulations, and requires either more active catalysts or bulk $\mathrm{CO}_{2}$ separation upstream to increase reactants concentrations. Projections on a full scale plant have allowed an early carbon emission assessment to be made. Carbon savings for biohydrogen in a commercial scale are more than four times greater than alternative technologies. The assessment shows that bioH $\mathrm{H}_{2}$ with $\mathrm{CCS}$ has a GHG intensity more than $230 \%$ lower than fossil gas. Even without CCS, bioH $\mathrm{bffers}_{2}$ an $82 \%$ reduction in emissions. Importantly, it offers the potential for substantially lower emissions than both electrolysis and SMR-derived hydrogen. 
In the future, a combination of different hydrogen production technologies associated with CCS could be able to meet the UK's entire gas demand with zero net emissions: the emissions from electrolysis or SMR with CCS would be balanced by the negative bioH $\mathrm{H}_{2}$ emissions and increased share of renewable energy in the electricity mix.

\section{Acknowledgements}

The authors wish to acknowledge Cadent, Advanced Plasma Power and Progressive Energy Ltd for the support provided through the experimental phase and pilot plant demonstration. The work was funded by Cadent under the Network Innovation Allowance (NIA) programme.

\section{References}

Abdoulmoumine, N. et al. (2015) 'A review on biomass gasification syngas cleanup', Applied Energy. doi: 10.1016/j.apenergy.2015.05.095.

Adhikari, S. and Fernando, S. (2006) 'Hydrogen membrane separation techniques', Industrial and Engineering Chemistry Research. doi: 10.1021/ie050644l.

Al-Salem, S. M. (2015) 'Carbon dioxide (CO2) emission sources in Kuwait from the downstream industry: Critical analysis with a current and futuristic view', Energy. doi: 10.1016/j.energy.2014.12.075.

Al-Salem, S. M. et al. (2017) 'A review on thermal and catalytic pyrolysis of plastic solid waste (PSW)', Journal of Environmental Management. doi: 10.1016/j.jenvman.2017.03.084.

Arena, U. and Gregorio, F. Di (2016) 'Fluidized bed gasification of industrial solid recovered fuels', Waste Management, 50, pp. 86-92. doi:

https://doi.org/10.1016/j.wasman.2016.02.011.

Argun, H., Gokfiliz, P. and Karapinar, I. (2017) 'Biohydrogen Production Potential of Different Biomass Sources', in Biohydrogen Production: Sustainability of Current Technology and Future Perspective. doi: 10.1007/978-81-322-3577-4_2.

Asadullah, M. (2014) 'Biomass gasification gas cleaning for downstream applications: A comparative critical review', Renewable and Sustainable Energy Reviews. doi: 10.1016/j.rser.2014.07.132.

Asgari, M. et al. (2014) 'Designing a commercial scale pressure swing adsorber for hydrogen purification', Petroleum and Coal. doi: 10.1016/j.cej.2009.09.013. 
Von Der Assen, N. et al. (2014) 'Life cycle assessment of CO2 capture and utilization: A tutorial review', Chemical Society Reviews. doi: 10.1039/c3cs60373c.

Balcombe, P. et al. (2018) 'The carbon credentials of hydrogen gas networks and supply chains', Renewable and Sustainable Energy Reviews. doi: 10.1016/j.rser.2018.04.089.

Barelli, L. et al. (2008) 'Hydrogen production through sorption-enhanced steam methane reforming and membrane technology: A review', Energy. doi: 10.1016/j.energy.2007.10.018.

Barisano, D. et al. (2017) 'Hydrogen production from biomass via gasification process: The results of the eu UnifHY project', in European Biomass Conference and Exhibition Proceedings.

Basu, P. (2010) Biomass Gasification Design Handbook, Biomass Gasification and Pyrolysis. doi: 10.1016/B978-0-12-374988-8.00005-2.

Bertuccioli, L. et al. (2014) 'Study on development of water electrolysis in the EU - Final Report', Fuel Cells and hydrogen Joint Undertaking, (February). Available at: http://www.fch-ju.eu/sites/default/files/study electrolyser_0-Logos_0_0.pdf.

Bocci, E. et al. (2014) 'Biomass to fuel cells state of the art: A review of the most innovative technology solutions', International Journal of Hydrogen Energy. doi: 10.1016/j.ijhydene.2014.09.022.

Borhani, T. N. G. et al. (2015) 'CO<inf $>2</$ inf > capture with potassium carbonate solutions: A state-of-the-art review', International Journal of Greenhouse Gas Control. doi: 10.1016/j.ijggc.2015.06.026.

Bridgwater, a. . (2003) 'Renewable fuels and chemicals by thermal processing of biomass', Chemical Engineering Journal, 91(2-3), pp. 87-102. doi: 10.1016/S1385-8947(02)00142-0.

Budinis, S. et al. (2018) 'An assessment of CCS costs, barriers and potential', Energy Strategy Reviews. doi: 10.1016/j.esr.2018.08.003.

Byun, Y. et al. (2010) 'Demonstration of thermal plasma gasification/vitrification for municipal solid waste treatment.', Environmental science \& technology, 44(17), pp. 66806684. doi: 10.1021/es101244u.

Chang, C. Y. et al. (2009) 'Characteristics of elements in waste ashes from a solid waste incinerator in Taiwan', Journal of Hazardous Materials, 165(1-3), pp. 766-773. doi: 10.1016/j.jhazmat.2008.10.059.

Cherubini, F., Bargigli, S. and Ulgiati, S. (2009) 'Life cycle assessment (LCA) of waste management strategies: Landfilling, sorting plant and incineration', Energy. doi: 10.1016/j.energy.2008.08.023.

Chong, M. L. et al. (2009) 'Biohydrogen production from biomass and industrial wastes by dark fermentation', International Journal of Hydrogen Energy. doi: 10.1016/j.ijhydene.2009.02.010.

Christensen, T. H. et al. (2009) 'C balance, carbon dioxide emissions and global warming potentials in LCA-modelling of waste management systems', Waste Management and 
Research. doi: 10.1177/0734242X08096304.

Defra (2014) 'Energy from Waste a guide to the debate', UK Governement.Department for Environment Food \& Rural Affairs, 2014(February), p. 53. doi:

10.1109/IECON.2016.7793031.

Dunleavy, J. K. (2006) 'Mercury as a catalyst poison', Platinum Metals Review. doi: $10.1595 / 147106706 \times 128403$.

Edwards, R. (Jrc/les) et al. (2007) WELL-TO-WHEELS ANALYSIS OF FUTURE AUTOMOTIVE FUELS AND WELL-to-WHEELS Report, Europe. doi: 10.2788/79018.

Evangelisti, S. et al. (2015) 'Life cycle assessment of conventional and two-stage advanced energy-from-waste technologies for municipal solid waste treatment', Journal of Cleaner Production, 100, pp. 212-223. doi: 10.1016/j.jclepro.2015.03.062.

Fabry, F. et al. (2013) 'Waste gasification by thermal plasma: A review', Waste and Biomass Valorization. doi: 10.1007/s12649-013-9201-7.

Di Giuliano, A. et al. (2018) 'Multicycle sorption enhanced steam methane reforming with different sorbent regeneration conditions: Experimental and modelling study', Chemical Engineering Journal. doi: 10.1016/j.cej.2018.09.035

Gokhale, A. A., Dumesic, J. A. and Mavrikakis, M. (2008) 'On the mechanism of lowtemperature water gas shift reaction on copper', Journal of the American Chemical Society. doi: 10.1021/ja0768237.

Gomez, E. et al. (2009) 'Thermal plasma technology for the treatment of wastes: A critical review', Journal of Hazardous Materials, pp. 614-626. doi: 10.1016/j.jhazmat.2008.04.017.

Götz, M. et al. (2016) 'Renewable Power-to-Gas: A technological and economic review', Renewable Energy, pp. 1371-1390. doi: 10.1016/j.renene.2015.07.066.

Granite, E. J. and O'Brien, T. (2005) 'Review of novel methods for carbon dioxide separation from flue and fuel gases', in Fuel Processing Technology. doi: 10.1016/j.fuproc.2005.01.001.

Granovskii, M., Dincer, I. and Rosen, M. A. (2006) 'Economic and environmental comparison of conventional, hybrid, electric and hydrogen fuel cell vehicles', Journal of Power Sources. doi: 10.1016/j.jpowsour.2005.11.086.

Hart, D. et al. (2015) Scenarios for deployment of hydrogen in contributing to meeting carbon budgets and the 2050 target.

Hodges, J. et al. (2015) 'Injecting hydrogen into the gas network - a literature search'. Available at: http://www.hse.gov.uk/research/rrpdf/rr1047.pdf.

Hua, T. et al. (2014) 'Status of hydrogen fuel cell electric buses worldwide', Journal of Power Sources. doi: 10.1016/j.jpowsour.2014.06.055.

HyARC (2017) Hydrogen Pipelines. Available at: https://h2tools.org/hyarc/hydrogendelivery.

Iulianelli, A. et al. (2016) 'Advances on methane steam reforming to produce hydrogen 
through membrane reactors technology: A review', Catalysis Reviews - Science and Engineering. doi: 10.1080/01614940.2015.1099882.

Kippers, M. J. et al. (2011) 'Pilot project on hydrogen injection in natural gas on Island of Ameland in the Netherlands', International Gas Union Research Conference. doi: 10.1002/fut.20151.

Kouchachvili, L. and Entchev, E. (2018) 'Power to gas and H2/NG blend in SMART energy networks concept', Renewable Energy. doi: 10.1016/j.renene.2018.02.088.

Ladebeck, J. R. and Wagner, J. P. (2003) 'Catalyst development for water-gas shift', in Handbook of Fuel Cells. doi: 10.1002/9780470974001.f302017.

Leclerc, A. and Larachi, F. (2015) 'Allothermal fluidized bed reactor for steam gasification of biomass', Instrumentation Science and Technology. doi: 10.1080/10739149.2015.1010090.

Lombardi, L., Carnevale, E. and Corti, A. (2015) 'A review of technologies and performances of thermal treatment systems for energy recovery from waste', Waste Management. doi: 10.1016/j.wasman.2014.11.010.

Luberti, M. et al. (2014) 'Design of a H2PSA for cogeneration of ultrapure hydrogen and power at an advanced integrated gasification combined cycle with pre-combustion capture', Adsorption. doi: 10.1007/s10450-013-9598-0.

Manson-Whitton, C. (2017) 'Biohydrogen: Production of hydrogen by gasification of waste An NIA assessment of Biohydrogen production and opportunities for implementation on the gas network Report for Andy Lewis, Cadent Gas Ltd Prepared by Progressive Energy Ltd and Advanced Plasma P', (July). Available at: www.progressive-energy.com.

Materazzi, M. et al. (2014) 'Tar evolution in a two stage fluid bed-plasma gasification process for waste valorization', Fuel Processing Technology, 128, pp. 146-157. doi: 10.1016/j.fuproc.2014.06.028.

Materazzi, M., Lettieri, P., Mazzei, L., et al. (2015) 'Fate and behavior of inorganic constituents of RDF in a two stage fluid bed-plasma gasification plant', Fuel, 150, pp. 473485. doi: 10.1016/j.fuel.2015.02.059.

Materazzi, M., Lettieri, P., Taylor, R., et al. (2015) 'The Fate of Ashes and Inorganics in a Twostage Fluid Particle System for Waste Valorization', Procedia Engineering, 102, pp. 936-944. doi: 10.1016/j.proeng.2015.01.215.

Materazzi, M. et al. (2016a) 'Performance analysis of RDF gasification in a two stage fluidized bed-plasma process', Waste Management, 47. doi:

10.1016/j.wasman.2015.06.016.

Materazzi, M. et al. (2016b) 'Performance analysis of RDF gasification in a two stage fluidized bed-plasma process', Waste Management, 47, pp. 256-266. doi: 10.1016/j.wasman.2015.06.016.

Materazzi, M. et al. (2018) 'Production of BioSNG from waste derived syngas: Pilot plant operation and preliminary assessment', Waste Management, 79, pp. 752-762. doi: https://doi.org/10.1016/j.wasman.2018.08.031. 
Materazzi, M. and Lettieri, P. (2017a) 'Fluidized Beds for the Thermochemical Processing of Waste', in Reference Module in Chemistry, Molecular Sciences and Chemical Engineering. Elsevier. doi: https://doi.org/10.1016/B978-0-12-409547-2.12180-8.

Materazzi, M. and Lettieri, P. (2017b) 'Fluidized Beds for the Thermochemical Processing of Waste', in Reference Module in Chemistry, Molecular Sciences and Chemical Engineering. doi: https://doi.org/10.1016/B978-0-12-409547-2.12180-8.

Miandad, R. et al. (2016) 'Catalytic pyrolysis of plastic waste: A review', Process Safety and Environmental Protection. doi: 10.1016/j.psep.2016.06.022.

Molino, A. et al. (2018) 'Biofuels production by biomass gasification: A review', Energies. doi: 10.3390/en11040811.

National Grid (2017) 'UK Future Energy Scenarios 2017', Energy, (July), p. 220. Available at: https://www.nationalgrid.com/NR/rdonlyres/C7B6B544-3E76-4773-AE799124DDBE5CBB/56766/UKFutureEnergyScenarios2012.pdf.

Ni, M. et al. (2006) 'An overview of hydrogen production from biomass', Fuel Processing Technology. doi: 10.1016/j.fuproc.2005.11.003.

Northern Gas Networks (2016) 'H21 Leeds City Gate', Leeds City Gate. doi: $10.1155 / 2008 / 830474$.

Ofgem (no date) The UK Solid and Gaseous Biomass Carbon Calculator, 2015. Available at: https://www.ofgem.gov.uk/publications-and-updates/uk-solid-and-gaseous-biomasscarbon-calculator (Accessed: 4 February 2019).

Ogden, J. M. (2018) Prospects for Hydrogen in the Future Energy System, Research Report UCD-ITS-RR-18-07.

Olajire, A. A. (2010) 'CO2capture and separation technologies for end-of-pipe applications A review', Energy. doi: 10.1016/j.energy.2010.02.030.

Rabou, L. P. L. M. and Bos, L. (2012) 'High efficiency production of substitute natural gas from biomass', Applied Catalysis B: Environmental. Elsevier B.V., 111-112, pp. 456-460. doi: 10.1016/j.apcatb.2011.10.034.

Ratnasamy, C. and Wagner, J. (2009) 'Water gas shift catalysis', Catalysis Reviews - Science and Engineering. doi: 10.1080/01614940903048661.

Rehling, B. et al. (2011) 'BioSNG-process simulation and comparison with first results from a 1-MW demonstration plant', Biomass Conversion and Biorefinery, 1(2), pp. 111-119. doi: 10.1007/s13399-011-0013-3.

Rubin, E. S. et al. (2012) 'The outlook for improved carbon capture technology', Progress in Energy and Combustion Science. doi: 10.1016/j.pecs.2012.03.003.

Sanlisoy, A. and Carpinlioglu, M. O. (2017) 'A review on plasma gasification for solid waste disposal', International Journal of Hydrogen Energy. doi: 10.1016/j.ijhydene.2016.06.008.

De Santoli, L., Paiolo, R. and Lo Basso, G. (2017) 'An overview on safety issues related to hydrogen and methane blend applications in domestic and industrial use', in Energy 
Procedia. doi: 10.1016/j.egypro.2017.08.224.

Seemann, M. C. et al. (2006) 'The regenerative effect of catalyst fluidization under methanation conditions', Applied Catalysis A: General, 313(1-2), pp. 14-21. doi: 10.1016/j.apcata.2006.06.048.

Shabani, B. and Andrews, J. (2015) 'Hydrogen and fuel cells', Green Energy and Technology. doi: 10.1007/978-81-322-2337-5_17.

Shokrollahi Yancheshmeh, M., Radfarnia, H. R. and Iliuta, M. C. (2016) 'High temperature $\mathrm{CO}<$ inf $>2</$ inf $>$ sorbents and their application for hydrogen production by sorption enhanced steam reforming process', Chemical Engineering Journal. doi:

10.1016/j.cej.2015.06.060.

Siedlecki, M. and de Jong, W. (2011) 'Biomass gasification as the first hot step in clean syngas production process - gas quality optimization and primary tar reduction measures in a $100 \mathrm{~kW}$ thermal input steam-oxygen blown CFB gasifier', Biomass and Bioenergy. Elsevier Ltd, 35(SUPPL. 1), pp. S40-S62. doi: 10.1016/j.biombioe.2011.05.033.

Smith R J, B., Loganathan, M. and Shantha, M. S. (2010) 'A Review of the Water Gas Shift Reaction Kinetics', International Journal of Chemical Reactor Engineering. doi: 10.2202/1542-6580.2238.

Tagliaferri, C. et al. (2016) 'Life cycle assessment of conventional and advanced two-stage energy-from-waste technologies for methane production', Journal of Cleaner Production. doi: 10.1016/j.jclepro.2016.04.092.

Takenaka, S., Shimizu, T. and Otsuka, K. (2004) 'Complete removal of carbon monoxide in hydrogen-rich gas stream through methanation over supported metal catalysts', International Journal of Hydrogen Energy. doi: 10.1016/j.ijhydene.2003.10.009.

Tancredi, N. et al. (1996) 'CO2 gasification of eucalyptus wood chars', Fuel, 75(13), pp. 1505-1508. doi: 10.1016/0016-2361(96)82641-X.

Verhelst, S., Wallner, T. and Sierens, R. (2014) 'Hydrogen-Fueled internal combustion engines', in Handbook of Hydrogen Energy. doi: 10.1201/b17226.

Wang, Q. et al. (2009) 'Thermal treatment of municipal solid waste incinerator fly ash using DC double arc argon plasma', Fuel. doi: 10.1016/j.fuel.2008.12.011.

Wilén, C. et al. (2004) 'Finnish expert report on best available techniques in energy production from solid recovered fuels', The Finnish Environment 688.

Wilk, V. et al. (2011) 'Gasification of waste wood and bark in a dual fluidized bed steam gasifier', Biomass Conversion and Biorefinery. doi: 10.1007/s13399-011-0009-z.

Witkowski, A. et al. (2018) 'Analysis of compression and transport of the methane/hydrogen mixture in existing natural gas pipelines', International Journal of Pressure Vessels and Piping. doi: 10.1016/j.ijpvp.2018.08.002.

Woolcock, P. J. and Brown, R. C. (2013) 'A review of cleaning technologies for biomassderived syngas', Biomass and Bioenergy. doi: 10.1016/j.biombioe.2013.02.036. 
Wu, Y. J. et al. (2016) 'Progress on sorption-enhanced reaction process for hydrogen production', Reviews in Chemical Engineering. doi: 10.1515/revce-2015-0043.

Zech, K. et al. (2015) 'Technical, economic and environmental assessment of technologies for the production of biohydrogen and its distribution', International Journal of Hydrogen Energy. doi: 10.1016/j.ijhydene.2015.01.177.

Zeng, K. and Zhang, D. (2010) 'Recent progress in alkaline water electrolysis for hydrogen production and applications', Progress in Energy and Combustion Science. doi: 10.1016/j.pecs.2009.11.002.

Zhang, W. (2010) 'Automotive fuels from biomass via gasification', in Fuel Processing Technology. doi: 10.1016/j.fuproc.2009.07.010.

Zwart, R. W. R. (2009) 'Gas cleaning downstream biomass gasification Status Report 2009', ECN SenterNovem. 